\title{
RESEARCH
}

Open Access

\section{Comparison common equations for LDL-C calculation with direct assay and developing a novel formula in Iranian children and adolescents: the CASPIAN V study}

Fatemeh Molavi ${ }^{1}$, Nazli Namazi ${ }^{2}$, Mojgan Asadi ${ }^{2 *}$ (D, Mahnaz Sanjari ${ }^{2}$, Mohammad Esmaeil Motlagh ${ }^{3}$, Gita Shafiee ${ }^{1}$ Mostafa Qorbani ${ }^{4,5^{*}}$, Ramin Heshmat ${ }^{1}$ and Roya Kelishadi ${ }^{6}$

\begin{abstract}
Background: Hypercholesterolemia is a common dyslipidemia that leads to atherosclerosis. It is proved that early stages of atherosclerosis begins in early stages of life. In several studies, widespread prevalence of dyslipidemia in children is reported. So, assessment of lipid profile in children and adolescence is necessary for early diagnosis of dyslipidemia. Laboratory methods for measuring LDL are not available and economical. So, in some laboratories Friedwald method is used to determine LDL level. But, the preciseness of this method is not acceptable. Further, the preciseness of this method was not assayed in children and adolescence. So, it seems that assaying the preciseness of different methods is necessary.
\end{abstract}

Methods: The methodology of this work is on the basis of findings of the Caspian $\vee$ study. This study was conducted in 30 provinces of Iran during 2015. The population of this work was rural and urban students aged 718 years old. The level of total cholesterol (TC), HDL, LDL, and TG were measured using laboratory methods. The average and variances values were determined for each group of data using SPSS. Further, LDL values were calculated with a new formula introduced in this work. A comparison was made between the new formula and the other methods.

Results: In the present study, we found that compare to four common formulas, Friedwald was the best equation to estimate LDL-C concentrations in Iranian children and adolescents and the new formula was the next accurate equation. The strongest correlation between Friedwald and the new equation was found for those with 15-18 years old.

(Continued on next page)

\footnotetext{
* Correspondence: asadim@tums.ac.ir; mqorbani1379@yahoo.com

${ }^{2}$ Diabetes Research Center, Endocrinology and Metabolism Clinical Sciences Institute, Tehran University of Medical Sciences, Tehran, Iran

${ }^{4}$ Non-communicable Diseases Research Center, Alborz University of Medical Sciences, Karaj, Iran

Full list of author information is available at the end of the article
}

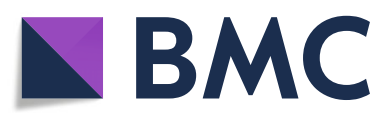

(- The Author(s). 2020 Open Access This article is licensed under a Creative Commons Attribution 4.0 International License, which permits use, sharing, adaptation, distribution and reproduction in any medium or format, as long as you give appropriate credit to the original author(s) and the source, provide a link to the Creative Commons licence, and indicate if changes were made. The images or other third party material in this article are included in the article's Creative Commons licence, unless indicated otherwise in a credit line to the material. If material is not included in the article's Creative Commons licence and your intended use is not permitted by statutory regulation or exceeds the permitted use, you will need to obtain permission directly from the copyright holder. To view a copy of this licence, visit http://creativecommons.org/licenses/by/4.0/ The Creative Commons Public Domain Dedication waiver (http://creativecommons.org/publicdomain/zero/1.0/) applies to the data made available in this article, unless otherwise stated in a credit line to the data. 
(Continued from previous page)

Conclusion: Considering the cut-off points of TG $(100 \mathrm{mg} / \mathrm{dL})$, we observed the strongest correlation between Friedwald equation and direct assay and the weakest one was for Ahmadi formula in subjects with either greater or lower TG concentrations. Furthermore, we found that Anandraja equation had the most sensitivity (89.5\%), while the most specificity was dedicated to the new formula (98.9\%).

Keywords: LDL level, Triglyceride, Children and adolescent

\section{Introduction}

According to pediatric advisory groups, selective screening for dyslipidemia in children is recommended particularly in those aged 2-18 years old with parents with precholestrolemia or other risk factors such as obesity and smoking. As there is an association between hyperlipidemia and cardiovascular diseases, controlling lipid profile can be helpful for primary and secondary preventions [1]. Since the basis of atherosclerosis and cardiovascular diseases start at early childhood, paying attention to lipid status is appreciated [2].

One of the crucial parameters used for CVD risk assessment is the serum level of low density lipoproteinCholesterol (LDL-C) [3, 4]. Various methods are used for measuring LDL-C concentrations. Although gold standard for LDL-C measurement is Ultracentrifugation following by betaquantification [5], it has several limitations. It is an expensive and time-consuming method that needs special equipments [6]. Therefore, it is not a common method for routine clinical measurements. Instead, other direct methods including homogenous assay techniques are usually used as well as various equations such as Friedewald, Chen and Anandaraja [7].

Although Friedewald formula is wildly used for reporting LDL-C, it features a fixed triglyceride (TG): very-low-density lipoprotein cholesterol (VLDL-C) ratio of 5:1. Accordingly, it cannot show the substantial inter-individual variability in TG: VLDL-C ratios [8]. Besides, the Friedewald equation is not applicable for those with fasting TG equal or higher than $400 \mathrm{mg} /$ $\mathrm{dL}$, and often this equation underestimates LDL-C concentrations in subjects with TG equal to $150 \mathrm{mg} /$ dL. Another limitation of Friedwald formula is related to being $8 \mathrm{~h}$ overnight fasting that is usually difficult for children. Finding non-fasting measurement method with acceptable accuracy for LDL-C is practically preferred in children [9].

Several studies compared the amount of LDL-C concentration obtained from formulas with each other or with a direct measurement [6, 8-13]. However, it seems most studies examined adult populations. To the best of our knowledge, there is few studies in which common equations for LDL-C calculation were compared with direct assay in children and adolescents at national level.

\section{Material \& Methods}

\section{Study population and sampling framework}

The present cross-sectional study was conducted on a sub sample from the CASPIAN $V$ study, a population-based study in Iran, on students aged 7 to 18 years old. To choose eligible individuals, multistage, cluster sampling method was used from 30 provinces in 2015. Details of sampling procedures was presented elsewhere [14]. Briefly, in each province, children and adolescent considering equal number for boys and girls stratified based on living place (urban/ rural) as well as the level of education (primary /secondary). To reach the calculated number of participants, multistage, stratified cluster sampling method was also applied in each province. The size of cluster was 10 (10 students with their parents). Of 14,400 students in the CASPIAN study, 3844 students were selected for biochemical measurements. It means 14 out of 48 clusters from each province were randomly selected for the current study.

In the first step, for eligible students and their parents, sufficient explanations regarding the purpose of the study and the procedures were provided. Then, written informed consent and verbal consent were obtained from parents and students, respectively. All assessments were performed for subjects who completed the written informed consent.

Health-care professional team asked characteristics of participants and completed all questionnaires at schools in a room, where away from busy classrooms and interviewing with at least one of students' parents.

\section{Biochemical assessments}

Eligible students with at least one of their parents were referred to the laboratory for biochemical tests. After 12 h overnight fasting, $6 \mathrm{~mL}$ venous blood sample was collected from students. All blood samples were centrifuged at $2500-3000 \times g$ for $10 \mathrm{~min}$ and then serum samples were aliquot and stored at $-70^{\circ} \mathrm{C}$ till measurement. Lipid profiles including TG, total cholesterol (TC), LDL$\mathrm{C}$ and high-density lipoprotein-cholesterol (HDL-C) were measured using enzymatic method by Hitachi Auto Analyzer (Tokyo, Japan). 
Table 1 Different equations for LDL-C calculation

\begin{tabular}{ll}
\hline Researchers & Formulas \\
\hline Friedwald & $\mathrm{LDL}=\mathrm{TC}-\mathrm{HDL}-(\mathrm{TG} / 5)$ \\
Ahmadi et al. & $\mathrm{LDL}=\mathrm{TC} / 1.19+\mathrm{TG} / 1.9-\mathrm{HDL} / 1.1-38$ \\
Chen & $\mathrm{LDL}=(0.9 \times \mathrm{TC})-(0.9 \times \mathrm{HDL})-(0.1 \times \mathrm{TG})$ \\
Anandaraja & $\mathrm{LDL}=(0.9 \times \mathrm{TC})-(0.9 \times \mathrm{TG} / 5)-28$ \\
New formula & $\mathrm{LDL}=(0.97 \times \mathrm{TC})-(0.93 \times \mathrm{HDL})-(0.19 \times \mathrm{TG})$ \\
\hline
\end{tabular}

\section{LDL-C calculation}

Apart from the measurement of LDL-C in serum samples, the amount of LDL-C was calculated using 4 common formulas as represented in Table 1.

Statistical analysis was performed on the data obtained from this assessed population. Accordingly, a regression model was developed. The developed model is as follows:

$$
\begin{aligned}
x_{L D L-C}= & \left(0.97 \times x_{T C}\right)-\left(0.19 \times x_{T G}\right) \\
& -\left(0.93 \times x_{H D L-C}\right)
\end{aligned}
$$

where $\mathrm{x}_{\mathrm{LDL}-\mathrm{C}}, \mathrm{x}_{\mathrm{TC}}, \mathrm{x}_{\mathrm{TG}}$, and $\mathrm{x}_{\mathrm{HDL}-\mathrm{C}}$ are values of LDL-C, TC, TG, and HDL-C, respectively.

It is worthwhile noting that this developed model was obtained from the subjects with $\mathrm{TG}<100 \mathrm{mg} / \mathrm{dL}$. Note that this regression model was extracted from data using SPSS software (SPSS Inc., USA). The mentioned equation was then examined and validated on children and adolescents with TG > $100 \mathrm{mg} /$ dL.

\section{Statistical analysis}

The correlation among equations and with a direct measurement was examined. Findings were reported in subjects with $\mathrm{TG}>100 \mathrm{mg} / \mathrm{dL}$ and $<100 \mathrm{mg} / \mathrm{dL}$, separately.

The coefficient of determination is an index for assessing the correlation between actual and predicted values. This index is calculated as follows:

$$
\begin{aligned}
& \mathrm{R}^{2}=1-\frac{\sum\left(\mathrm{x}_{\text {act. }}-\mathrm{x}_{\text {pred. }}\right)^{2}}{\sum\left(\mathrm{x}_{\text {act. }}-\mathrm{x}_{\text {ave. }}\right)^{2}} \\
& \mathrm{x}_{\text {ave. }}=\frac{\sum \mathrm{x}_{\text {act. }}}{\mathrm{n}}
\end{aligned}
$$

where $\mathrm{x}_{\text {act. }}, \mathrm{x}_{\text {pred. }}$, and $\mathrm{n}$ are the actual value, predicted value, and number of data, respectively.

Considering $110 \mathrm{mg} / \mathrm{dL}$ as a cut-off, sensitivity and specificity for each formula in all participants as well as those with low $(<100 \mathrm{mg} / \mathrm{dL})$ and high TG $(>100 \mathrm{mg} /$ $\mathrm{dL}$ ) were presented. Youden index, (sensitivity + specificity)-100, was calculated for each in order to identify the best formula for LDL-C calculation in Iranian children and adolescents.

\section{Results}

Findings are presented for 3844 children and adolescents categorized based on gender, age and residential place. As depicted in Table 2, the frequency of subjects with TG $>100 \mathrm{mg} / \mathrm{dL}$ was greater than those with $\mathrm{TG}<100$ $\mathrm{mg} / \mathrm{dL}$ in all age categories (higher than $70 \%$ for all). The percentage of boys with TG $>100 \mathrm{mg} / \mathrm{dL}$ was higher than girls (73.1 vs.71.4\%). However, the difference between genders was not considerable. Classifications by residential place showed that participants lived in rural places had higher TG concentrations than whom resident in urban regions (73.5 vs.71.8\%, respectively).

Based on Table 3, there were no significant differences in LDL-C concentrations obtained from formulas except Anandraja ( $p=0.18)$ when subjects were classified based on the cut-off point of $100 \mathrm{mg} / \mathrm{dL}$ for TG.

In Table 4, the correlation between predicted formulas with each other and direct assay are provided. In general, Friedwald formula $(r=0.982)$ stood at the first rank for the correlation with direct assay and the second rank was dedicated to the new formula $(r=0.978)$. The lowest correlation was observed for Ahmadi formula $(r=0.553)$. In subjects with $\mathrm{TG}>100 \mathrm{mg} / \mathrm{dL}$, the strongest correl-

\begin{tabular}{|c|c|c|c|c|c|c|c|}
\hline & & \multicolumn{2}{|l|}{ Total } & \multicolumn{2}{|c|}{$\mathrm{TG}>100$} & \multicolumn{2}{|c|}{ TG $<100$} \\
\hline & & $\mathrm{N}$ & Percentage & $\mathrm{N}$ & Percentage & $\mathrm{N}$ & Percentage \\
\hline \multirow[t]{3}{*}{ Age } & $7-10$ & 1147 & 29 & 848 & 73.9 & 299 & 26.1 \\
\hline & $11-14$ & 1655 & 44 & 1198 & 72.4 & 457 & 27.6 \\
\hline & $15-18$ & 1042 & 27 & 733 & 70.3 & 309 & 29.7 \\
\hline \multirow[t]{2}{*}{ Sex } & Female & 1831 & 47.6 & 1307 & 71.4 & 524 & 28.6 \\
\hline & Male & 2013 & 52.4 & 1472 & 73.1 & 541 & 26.9 \\
\hline \multirow[t]{2}{*}{ Region } & Urban & 2749 & 72 & 1994 & 71.8 & 782 & 28.2 \\
\hline & Rural & 1068 & 28 & 785 & 73.5 & 283 & 26.5 \\
\hline
\end{tabular}
ation was found between direct assay and Friedwald equation $(r=0.979)$ followed by the new formula ( $n=$

Table 2 Frequency of subjects with TG levels lower and higher than $100 \mathrm{mg} / \mathrm{dl}$ in terms of age, sex and region 
Table 3 Mean and standard deviation of lipid levels

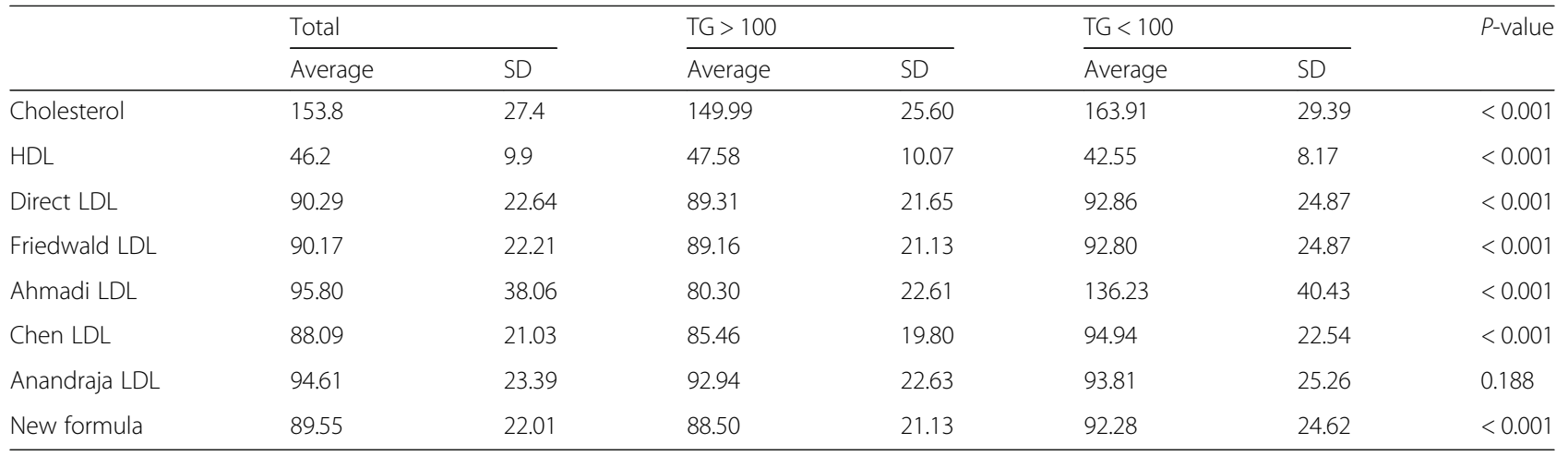

0.974). The weakest correlation was observed for Ahmadi formula $(r=0.839)$. Similar findings were obtained for those with TG $>100 \mathrm{mg} / \mathrm{dL}$. However, stronger correlation was obtained for Friedwald $(r=0.986)$ and lowest association was seen for Ahmadi formula $(r=0.553)$ compared to whom with TG $<100 \mathrm{mg} / \mathrm{dL}$.

As presented in Table 5, the strongest correlation between Friedwald and the new equation was found for those with $15-18$ years old ( $r=0.987$ ), while the weakest correlation was related to Ahmadi formula for whom with $11-14$ years old $(r=0.545)$.

Sensitivity and specificity of various methods are provided in Table 6. In general, we found that Anandraja equation had the most sensitivity $(89.5 \%)$, while the most specificity was for the new formula (98.9\%). Considering the Yuden index, Friedwald obtained the first rank
(86.2\%) that is followed by the new formula (84.2\%). After classification by cut-off point of $100 \mathrm{mg} / \mathrm{dL}$ for TG concentrations, it was revealed that the most amount for Yuden index was for Friedwald for both categories (TG < $100 \mathrm{mg} / \mathrm{dL}: 86.6 \%$; TG > $100 \mathrm{mg} / \mathrm{dL}: 85 \%)$.

\section{Discussion}

In the present study, we found that compare to four common formulas, Friedwald was the best equation to estimate LDL-C concentrations in Iranian children and adolescents and the new formula was the next accurate equation.

One of main identified potential risk factors for CVD and atherosclerosis in adulthood is high concentration of LDL-C. Research in children and adolescents has revealed that monitoring lipid profile status at young age

Table 4 Correlatin between LDL-C level for different methods

\begin{tabular}{|c|c|c|c|c|c|c|c|}
\hline & & Ahmadi LDL & Friedwald LDL & Direct LDL & Anandraja LDL & Chen LDL & New formula \\
\hline \multirow[t]{6}{*}{$\mathrm{TG}<100$} & Ahmadi LDL & 1 & 0.857 & 0.839 & 0.729 & 0.880 & 0.847 \\
\hline & Friedwald LDL & 0.857 & 1 & 0.979 & 0.913 & 0.989 & 0.991 \\
\hline & Direct LDL & 0.839 & 0.979 & 1 & 0.901 & 0.972 & 0.974 \\
\hline & Anandraja LDL & 0.729 & 0.913 & 0.901 & 1 & 0.910 & 0.925 \\
\hline & Chen LDL & 0.880 & 0.989 & 0.972 & 0.910 & 1 & 0.998 \\
\hline & New formula & 0.847 & 0.991 & 0.974 & 0.925 & 0.998 & 1 \\
\hline \multirow[t]{6}{*}{$\mathrm{TG}>100$} & Ahmadi LDL & 1 & 0.515 & 0.503 & 0.445 & 0.658 & 0.520 \\
\hline & Friedwald LDL & 0.515 & 1 & 0.986 & 0.954 & 0.984 & 1.00 \\
\hline & Direct LDL & 0.503 & 0.986 & 1 & 0.942 & 0.969 & 0.986 \\
\hline & Anandraja LDL & 0.445 & 0.954 & 0.942 & 1 & 0.930 & 0.957 \\
\hline & Chen LDL & 0.658 & 0.984 & 0.969 & 0.930 & 1 & 0.985 \\
\hline & New formula & 0.520 & 1.00 & 0.986 & 0.957 & 0.985 & 1 \\
\hline \multirow[t]{6}{*}{ Total } & Ahmadi LDL & 1 & 0.566 & 0.553 & 0.430 & 0.696 & 0.566 \\
\hline & Friedwald LDL & 0.566 & 1 & 0.982 & 0.922 & 0.979 & 0.994 \\
\hline & Direct LDL & 0.553 & 0.982 & 1 & 0.910 & 0.963 & 0.978 \\
\hline & Anandraja LDL & 0.430 & 0.922 & 0.910 & 1 & 0.893 & 0.931 \\
\hline & Chen LDL & 0.696 & 0.979 & 0.963 & 0.893 & 1 & 0.986 \\
\hline & New formula & 0.566 & 0.994 & 0.978 & 0.931 & 0.986 & 1 \\
\hline
\end{tabular}


Table 5 Correlation between different LDL-C calcuation methods in terms of age

\begin{tabular}{|c|c|c|c|c|c|c|c|c|c|c|c|}
\hline & & & Ahmadi LDL & Friedwald LDL & Direct LDL & TG & TC & $\mathrm{HDL}$ & Anandraja LDL & Chen LDL & New formula \\
\hline \multirow[t]{36}{*}{ Age } & \multirow[t]{9}{*}{$7-10$} & Ahmadi LDL & 1 & 0.576 & 0.562 & 0.865 & 0.691 & -0.145 & 0.440 & 0.699 & 0.576 \\
\hline & & Friedwald LDL & 0.576 & 1 & 0.977 & 0.090 & 0.913 & 0.176 & 0.924 & 0.980 & 0.994 \\
\hline & & Direct LDL & 0.562 & 0.977 & 1 & 0.090 & 0.913 & 0.176 & 0.924 & 0.980 & 0.974 \\
\hline & & TG & 0.865 & 0.090 & 0.088 & 1 & 0.291 & -0.270 & -0.022 & 0.254 & 0.095 \\
\hline & & $\mathrm{TC}$ & 0.691 & 0.913 & 0.896 & 0.291 & 1 & 0.420 & 0.950 & 0.938 & 0.923 \\
\hline & & $\mathrm{HDL}$ & -0.145 & 0.176 & 0.179 & -0.270 & 0.420 & 1 & 0.527 & 0.122 & 0.186 \\
\hline & & Anandraja LDL & 0.440 & 0.924 & 0.908 & -0.022 & 0.950 & 0.527 & 1 & 0.897 & 0.933 \\
\hline & & Chen LDL & 0.699 & 0.980 & 0.960 & 0.254 & 0.938 & 0.122 & 0.897 & 1 & 0.987 \\
\hline & & New formula & 0.576 & 0.994 & 0.974 & 0.095 & 0.923 & 0.186 & 0.933 & 0.987 & 1 \\
\hline & \multirow[t]{9}{*}{$11-14$} & Ahmadi LDL & 1 & 0.559 & 0.545 & 0.884 & 0.691 & -0.173 & 0.416 & 0.691 & 0.557 \\
\hline & & Friedwald LDL & 0.559 & 1 & 0.985 & 0.107 & 0.901 & 0.131 & 0.917 & 0.975 & 0.991 \\
\hline & & Direct LDL & 0.545 & 0.985 & 1 & 0.099 & 0.891 & 0.133 & 0.908 & 0.963 & 0.980 \\
\hline & & TG & 0.884 & 0.107 & 0.099 & 1 & 0.329 & -0.267 & -0.009 & 0.282 & 0.113 \\
\hline & & $\mathrm{TC}$ & 0.691 & 0.901 & 0.891 & 0.329 & 1 & 0.380 & 0.941 & 0.933 & 0.914 \\
\hline & & $\mathrm{HDL}$ & -0.173 & 0.131 & 0.133 & -0.267 & 0.380 & 1 & 0.498 & 0.070 & 0.137 \\
\hline & & Anandraja LDL & 0.416 & 0.917 & 0.908 & -0.009 & 0.941 & 0.498 & 1 & 0.887 & 0.927 \\
\hline & & Chen LDL & 0.691 & 0.975 & 0.963 & 0.282 & 0.933 & 0.070 & 0.887 & 1 & 0.985 \\
\hline & & New formula & 0.557 & 0.991 & 0.980 & 0.113 & 0.914 & 0.137 & 0.927 & 0.985 & 1 \\
\hline & \multirow[t]{9}{*}{$15-18$} & Ahmadi LDL & 1 & 0.568 & 0.557 & 0.879 & 0.714 & -0.146 & 0.443 & 0.704 & 0.571 \\
\hline & & Friedwald LDL & 0.568 & 1 & 0.987 & 0.107 & 0.909 & 0.141 & 0.929 & 0.984 & 1.00 \\
\hline & & Direct LDL & 0.557 & 0.987 & 1 & 0.101 & 0.900 & 0.152 & 0.921 & 0.971 & 0.987 \\
\hline & & $\mathrm{TG}$ & 0.879 & 0.107 & 0.101 & 1 & 0.342 & -0.241 & 0.003 & 0.280 & 0.110 \\
\hline & & $\mathrm{TC}$ & 0.714 & 0.909 & 0.900 & 0.342 & 1 & 0.387 & 0.941 & 0.938 & 0.915 \\
\hline & & $\mathrm{HDL}$ & -0.146 & 0.141 & 0.152 & -0.241 & 0.387 & 1 & 0.498 & 0.094 & 0.156 \\
\hline & & Anandraja LDL & 0.443 & 0.929 & 0.921 & 0.003 & 0.941 & 0.498 & 1 & 0.897 & 0.934 \\
\hline & & LDL-Chen & 0.704 & 0.984 & 0.971 & 0.280 & 0.938 & 0.094 & 0.897 & 1 & 0.985 \\
\hline & & New formula & 0.571 & 1.00 & 0.987 & 0.110 & 0.915 & 0.156 & 0.934 & 0.985 & 1 \\
\hline & \multirow[t]{9}{*}{ Total } & Ahmadi LDL & 1 & 0.566 & 0.553 & 0.876 & 0.697 & -0.157 & 0.430 & 0.696 & 0.566 \\
\hline & & Friedwald LDL & 0.566 & 1 & 0.982 & 0.101 & 0.907 & 0.149 & 0.922 & 0.979 & 0.994 \\
\hline & & Direct LDL & 0.553 & 0.982 & 1 & 0.096 & 0.894 & 0.155 & 0.910 & 0.963 & 0.978 \\
\hline & & TG & 0.876 & 0.101 & 0.096 & 1 & 0.319 & -0.262 & -0.011 & 0.272 & 0.106 \\
\hline & & $\mathrm{TC}$ & 0.697 & 0.907 & 0.894 & 0.319 & 1 & 0.396 & 0.944 & 0.936 & 0.917 \\
\hline & & $\mathrm{HDL}$ & -0.157 & 0.149 & 0.155 & -0.262 & 0.396 & 1 & 0.509 & 0.094 & 0.159 \\
\hline & & Anandraja LDL & 0.430 & 0.922 & 0.910 & 0.011 & 0.944 & 0.509 & 1 & 0.893 & 0.931 \\
\hline & & Chen LDL & 0.696 & 0.979 & 0.963 & 0.272 & 0.936 & 0.094 & 0.893 & 1 & 0.986 \\
\hline & & New formula & 0.566 & 0.994 & 0.978 & 0.106 & 0.917 & 0.159 & 0.931 & 0.986 & 1 \\
\hline
\end{tabular}

can be helpful to prevent CVD at adulthood [15]. Accordingly, studding on various methods to find the most accurate one can be helpful to reduce CVD events.

To the best of our knowledge, most studies on comparing formulas to estimate LDL-C concentrations have been conducted on adult populations $[6,7,12,13,16$, 17]. Martin et al., examined four equations including Friedewald, Chen, de Cordova, and Hattori compare to direct measurement in hospitalized patients in South
Africa. They found a favorable correlation between the de Cordova formula and Friedewald at low TG concentrations. However, the Hattori formula was the best equation to estimate LDL-C in hospitalized patients, even at extreme lipid values [13]. According to Wadhwa et al.,'s study, among 7 formulas, Friedewald, Cordova, Vujovic, Ahmadi, Anandaraja, Puavillai and Hattori, Vujovic formula was the most accurate one in Indian adult population [18]. Krishnavena et al., also reported 
Table 6 Sensitivity and specificity of different LDL-C calculation methods

\begin{tabular}{|c|c|c|c|c|c|c|c|c|c|c|}
\hline & & & \multicolumn{4}{|c|}{ Direct LDL } & \multirow[t]{3}{*}{ Sensitivity } & \multirow[t]{3}{*}{ Specificity } & \multirow{3}{*}{$\begin{array}{l}\text { Youden } \\
\text { index }\end{array}$} & \multirow[t]{3}{*}{$p$-value } \\
\hline & & & \multicolumn{2}{|c|}{$110>$} & \multicolumn{2}{|c|}{$110<$} & & & & \\
\hline & & & $\bar{N}$ & Percentage & $\bar{N}$ & Percentage & & & & \\
\hline \multirow[t]{10}{*}{ Total } & Ahmadi LDL & Low & 2539 & 80.7 & 230 & 33 & 67 & 80.7 & 47.7 & $<0.001$ \\
\hline & & High & 609 & 19.3 & 466 & 67 & & & & \\
\hline & Friedwald LDL & Low & 3087 & 98.1 & 83 & 11.9 & 88.1 & 98.1 & 86.2 & $<0.001$ \\
\hline & & High & 61 & 1.9 & 613 & 88.1 & & & & \\
\hline & Anandraja LDL & Low & 2850 & 90.5 & 73 & 10.5 & 89.5 & 90.5 & 80 & $<0.001$ \\
\hline & & High & 298 & 9.5 & 623 & 89.5 & & & & \\
\hline & Chen LDL & Low & 3108 & 98.7 & 187 & 26.9 & 73.1 & 98.7 & 71.8 & $<0.001$ \\
\hline & & High & 40 & 1.3 & 509 & 73.1 & & & & \\
\hline & New formula & Low & 3113 & 98.9 & 102 & 14.7 & 85.3 & 98.9 & 84.2 & $<0.001$ \\
\hline & & High & 35 & 1.1 & 594 & 85.3 & & & & \\
\hline \multirow[t]{10}{*}{$\mathrm{TG}<100$} & Ahmadi LDL & Low & 2269 & 98.1 & 230 & 49.5 & 50.5 & 98.1 & 48.6 & $<0.001$ \\
\hline & & High & 45 & 1.9 & 235 & 50.5 & & & & \\
\hline & Friedwald LDL & Low & 2273 & 98.2 & 54 & 11.6 & 88.4 & 98.2 & 86.6 & $<0.001$ \\
\hline & & High & 41 & 1.8 & 411 & 88.4 & & & & \\
\hline & Anandraja LDL & Low & 2076 & 89.7 & 44 & 9.5 & 90.5 & 89.7 & 80.2 & $<0.001$ \\
\hline & & High & 238 & 10.3 & 421 & 90.5 & & & & \\
\hline & Chen LDL & Low & 2310 & 99.8 & 155 & 33.3 & 66.7 & 99.8 & 66.5 & $<0.001$ \\
\hline & & High & 4 & 0.2 & 310 & 66.7 & & & & \\
\hline & New formula & Low & 2291 & 99 & 66 & 14.2 & 85.8 & 99 & 84.8 & $<0.001$ \\
\hline & & High & 23 & 1 & 399 & 85.8 & & & & \\
\hline \multirow[t]{10}{*}{$\mathrm{TG}>100$} & Ahmadi LDL & Low & 270 & 32.4 & 0 & 0 & 100 & 32.4 & 32.4 & $<0.001$ \\
\hline & & High & 564 & 67.6 & 231 & 100 & & & & \\
\hline & Friedwald LDL & Low & 814 & 97.6 & 29 & 12.6 & 87.4 & 97.6 & 85 & $<0.001$ \\
\hline & & High & 20 & 2.4 & 202 & 87.4 & & & & \\
\hline & Anandraja LDL & Low & 774 & 92.8 & 29 & 12.6 & 87.4 & 92.8 & 80.2 & $<0.001$ \\
\hline & & High & 60 & 7.2 & 202 & 87.4 & & & & \\
\hline & Chen LDL & Low & 798 & 95.7 & 32 & 13.9 & 86.1 & 95.7 & 81.8 & $<0.001$ \\
\hline & & High & 36 & 4.3 & 199 & 86.1 & & & & \\
\hline & New formula & Low & 822 & 98.6 & 36 & 15.6 & 84.4 & 98.6 & 83 & $<0.001$ \\
\hline & & High & 12 & 1.4 & 195 & 84.4 & & & & \\
\hline
\end{tabular}

that Friedwald correlated maximally with direct measurement of LDL-C at all levels of TG except at TG less than $100 \mathrm{mg} / \mathrm{dL}$ in an Indian adult population. They found that for subjects with serum levels of TG $<100$ $\mathrm{mg} / \mathrm{dl}$, Anandaraja's Formula was the most accurate equation [19]. Different findings between our study and the aforementioned ones are likely to be due to differences in age range, race, and different estimation formulas.

Ahmadi et al., reported that in Iranian adult subjects with low TG concentrations and undesirably high TC, Friedewald equation may overestimate LDL-C. Therefore, they suggested a new formula for such subjects and named it as Admadi formula [20]. Although Ahmadi equation was developed based on Iranian adult populations [20], we found that it cannot be appropriate for children and adolescents and it showed the lowest correlation with direct measurement $(r=0.553)$. Accordingly, we can conclude that considering age range plays a crucial role on choosing an accurate estimation formula.

It seems only one study compared LDL-C formulas in subjects younger than 18 years old [9]. Garoufi et al., compared calculated LDL-C using Anandaraja and Friedwald formulas with directly measured LDL-C in 1005 healthy and dyslipidemic children (age range: 2-18 
yrs. old) in Greece. They showed that using Friedwald formula, serum levels of LDL-C was lower than the measured value in $75.6 \%$ of healthy and in $77.3 \%$ of dyslipidemic children. They also found that Friedwald formula was more accurate screening tool compared to Anandaraja equation in healthy participants, while Anandaraja was more appropriate for following-up dyslipidemic children [9]. Our findings were in line with the mentioned study. In our study, Friedwald equation was the most accurate one. However, we did not do a classification based on LDL-C to compare healthy and dyslipidemic children. In addition, the correlation between Friedwald and direct assay was a little bit greater in our study compare to Garoufi et al'.,s study (0.98 vs. 0.97).

Although Frielwald formula has several limitations, it seems this formula is still the most accurate one compare to the other four formulas in our children and adolescent society.

Our study had several limitations. First, we did not use a reference method to measure LDL-C. Second, the comparisons were conducted only among four common formulas and we cannot make a decision regarding the accuracy of other estimation formulas. Third, we cannot clarify whether the new formula can be accurate for non-fasting measurements or not. However, the present study seems to be the first study to compare estimation LDL-C formulas among children and adolescents at national levels in Asia. We also compared estimation formulas for both lower and higher TG values. In addition, we developed and introduced a new formula with relatively similar accuracy to Friedwald on a representative sample of our children and adolescent society. In the present study, apart from correlations of equations with direct assay, sensitivity, specificity and the Yuden index for each were also reported.

\section{Conclusion}

It is concluded that Friedwald was the best equation to estimate LDL-C concentrations in Iranian children and adolescents and the new formula was the next accurate equation. In addition, Friedwald formula was the most accurate formula to estimate LDL-C in children and adolescent with either low or high TG values.

\section{Abbreviations}

LDL-C: Low density lipoprotein-Cholesterol; TG: Triglyceride; VLDL-C: Verylow-density lipoprotein cholesterol; TC: Total cholesterol; HDL-C: High-density lipoprotein-cholesterol; $R^{2}$ : Coefficient of determination

\section{Acknowledgements}

The authors appreciate the contribution of all participants of this project.

\section{Authors' contributions}

F. Molavi, M. Asadi, M. Qorbani, M. Sanjari, data analysis or interpretation N. Namazi, M. Esmaeil Motlagh,G. Shafiee, R. Heshmat, R. Kelishadi, data collection and processing. The authors read and approved the final manuscript.
Funding

There is no fund for this project.

Availability of data and materials

The data was obtained from the corresponding author.

Ethics approval and consent to participate

This study was approved by the research and ethics council of Tehran University of Medical science.

\section{Consent for publication}

All authors agreed with the publication of this work.

\section{Competing interests}

There is no conflict of interests.

\section{Author details}

${ }^{1}$ Chronic Diseases Research Center, Endocrinology and Metabolism Population Sciences Institute, Tehran University of Medical Sciences, Tehran, Iran. ${ }^{2}$ Diabetes Research Center, Endocrinology and Metabolism Clinical Sciences Institute, Tehran University of Medical Sciences, Tehran, Iran. ${ }^{3}$ Department of Pediatrics, Ahvaz Jundishapur University of Medical Sciences, Ahvaz, Iran. ${ }^{4}$ Non-communicable Diseases Research Center, Alborz University of Medical Sciences, Karaj, Iran. ${ }^{5}$ Endocrinology and Metabolism Research Center, Endocrinology and Metabolism Clinical Sciences Institute, Tehran University of Medical Sciences, Tehran, Iran. ${ }^{6}$ Child Growth and Development Research Center, Research Institute for Primordial Prevention of Non-communicable Disease, Isfahan University of Medical Sciences, Isfahan, Iran.

Received: 26 January 2020 Accepted: 28 May 2020

Published online: 06 June 2020

\section{References}

1. Fox KM, Wang L, Gandra SR, Quek RG, Li L, Baser O. Clinical and economic burden associated with cardiovascular events among patients with hyperlipidemia: a retrospective cohort study. BMC Cardiovasc Disord. 2016; 16(1):13.

2. Derinoz O, Tumer L, Hasanoglu A, Pasaoglu H, Aksakal FN, Ceyhan MN. Cholesterol screening in school children: is family history reliable to choose the ones to screen? Acta Paediatr. 2007;96(12):1794-8.

3. Silverman MG, Ference BA, Im K, Wiviott SD, Giugliano RP, Grundy SM, et al. Association between lowering LDL-C and cardiovascular risk reduction among different therapeutic interventions: a systematic review and metaanalysis. JAMA. 2016;316(12):1289-97.

4. El Harchaoui K, van der Steeg WA, Stroes ES, Kuivenhoven JA, Otvos JD, Wareham NJ, et al. Value of low-density lipoprotein particle number and size as predictors of coronary artery disease in apparently healthy men and women: the EPIC-Norfolk prospective population study. J Am Coll Cardiol. 2007:49(5):547-53.

5. Dong J, Guo H, Yang R, Li H, Wang S, Zhang J, et al. Serum LDL-and HDLcholesterol determined by ultracentrifugation and HPLC. J Lipid Res. 2011; 52(2):383-8.

6. Warade JP, Dahake H, Kavitha R. Comparison between direct estimation of LDL and Friedewald's formula. IAIM. 2016:3(2):10-7.

7. Oliveira MJA, van Deventer HE, Bachmann LM, Warnick GR, Nakajima K, Nakamura $\mathrm{M}$, et al. Evaluation of four different equations for calculating LDL-C with eight different direct HDL-C assays. Clin Chim Acta. 2013;423: 135-40.

8. Palmer MK, Barter PJ, Lundman P, Nicholls SJ, Toth PP, Karlson BW. Comparing a novel equation for calculating low-density lipoprotein cholesterol with the Friedewald equation: a VOYAGER analysis. Clin Biochem. 2019:64:24-9.

9. Garoufi A, Drakatos A, Tsentidis C, Klinaki E, Paraskakis I, Marmarinos A, et al. Comparing calculated LDL-C with directly measured LDL-C in healthy and in dyslipidemic children. Clin Biochem. 2017:50(1-2):16-22.

10. Bairaktari E, Hatzidimou K, Tzallas C, Vini M, Katsaraki A, Tselepis A, et al. Estimation of LDL cholesterol based on the Friedewald formula and on apo B levels. Clin Biochem. 2000;33(7):549-55.

11. Harry HY, Markowitz R, De Ferranti SD, Neufeld EJ, Farrow G, Bernstein HH, et al. Direct measurement of LDL-C in children: performance of two 
surfactant-based methods in a general pediatric population. Clin Biochem. 2000;33(2):89-95.

12. Martin SS, Blaha MJ, Elshazly MB, Toth PP, Kwiterovich PO, Blumenthal RS, et al. Comparison of a novel method vs the Friedewald equation for estimating low-density lipoprotein cholesterol levels from the standard lipid profile. JAMA. 2013;310(19):2061-8.

13. Martins J, Olorunju SA, Murray L, Pillay TS. Comparison of equations for the calculation of LDL-cholesterol in hospitalized patients. Clin Chim Acta. 2015; 444:137-42.

14. Motlagh ME, Ziaodini $H$, Qorbani M, Taheri M, Aminaei T, Goodarzi A, et al. Methodology and early findings of the fifth survey of childhood and adolescence surveillance and prevention of adult noncommunicable disease: the CASPIAN-V study. Int J Prev Med. 2017;8. https://doi.org/10. 4103/2008-7802.198915.

15. Daniels SR, Greer FR. Lipid screening and cardiovascular health in childhood. Pediatrics. 2008;122(1):198-208.

16. Nigam PK. Calculated low density lipoprotein-cholesterol: Friedewald's formula versus other modified formulas: calculated LDL-cholesterol. Int $J$ Life Sci Med Res. 2014;4(2):25.

17. Puavilai W, Laoragpongse D. Is calculated LDL-C by using the new modified Friedewald equation better than the standard Friedewald equation? J Med Assoc Thai. 2004:87(6):589-93.

18. Wadhwa N, Krishnaswamy R. Comparison of LDL-cholesterol estimate using various formulae with directly measured LDL-cholesterol in Indian population. J Clin Diagn Res. 2016;10(12):BC11.

19. Krishnaveni P, Gowda VM. Assessing the validity of Friedewald's formula and Anandraja's formula for serum LDL-cholesterol calculation. J Clin Diagn Res. 2015;9(12):BC01.

20. Ahmadi SA, Boroumand M-A, Gouhari MK, Tajik P, Dibaj S-M. The impact of low serum triglyceride on LDL-cholesterol estimation; 2008.

\section{Publisher's Note}

Springer Nature remains neutral with regard to jurisdictional claims in published maps and institutional affiliations.

Ready to submit your research? Choose BMC and benefit from:

- fast, convenient online submission

- thorough peer review by experienced researchers in your field

- rapid publication on acceptance

- support for research data, including large and complex data types

- gold Open Access which fosters wider collaboration and increased citations

- maximum visibility for your research: over $100 \mathrm{M}$ website views per year

At $\mathrm{BMC}$, research is always in progress.

Learn more biomedcentral.com/submissions 